\title{
Theoretical Reflections on Legal Pluralism and Global Constitutionalism: Their Possible Reconciliation in an Alternative Model of Plural Constitutionalism
}

\begin{abstract}
Over the past few decades, the complex process of globalization has dissolved the traditional concept of state sovereignty and neutralized the clear distinction between national and international law. Thus, legal scholarship has formulate alternative conceptual schemes to frame the fragmentation of the new global legal order. In the paper, I focus on the two typically antithetical approaches of legal pluralism and global constitutionalism. Legal pluralism emphasizes the diversity and the multiplicity of the global legal realm, while global constitutionalism is traditionally related to concepts of unity and hierarchy, whose paradigmatic reference is the state. The aim of the inquiry is to establish a theoretical basis and provide the conceptual tools to reconcile the two opposite approaches, first describing the main traits of each model, and then hypothesizing a hybrid model of plural constitutionalism. In the end, I will raise the question, from a constitutional but open point of view, whether it is really worth continuing to adopt a constitutional prospect. Alternative models (the GAL approach, for instance) may provide more suitable solutions for the complexity of the global legal world. However, a multiple model that attempts to reconcile different approaches, in correspondence to the multiplicity of the current global society, could be the best option.
\end{abstract}

Keywords: legal pluralism, global constitutionalism, plural constitutionalism, global governance, globalization, global administrative law

\section{Introduction}

Over the past few decades, the complex process of globalization ${ }^{1}$ has caused radical changes in today's legal world. Economic, cultural, political, social and migratory globalizing forces have dissolved the central power of the nation state into several sites of authority ${ }^{2}$ around the world, and have diluted it to such an extent to undermine the traditional concept of state sovereignty. Inevitably, the classic categories national law/international law have become increasingly blurred and are not able to include anymore all the different manifestations of law in the world society.

* Ph.D. Candidate in Comparative Law, Department of Criminal and Comparative Law, University of Florence, Piazza di San Marco, 4 - 50121 Firenze, Italy.

E-mail: lucrezia.palandri@unifi.it

1 The term "globalization" bears a negative ideological connotation since it has been overused, too often associated to politics-in the opposition between the two conflicting movements global/noglobal, in the economic imperialism of the multinationals, in the G8 riots. However, it is useful because it manages to evoke the idea of the demise of national borders, which become porous and allow a continuous osmosis of values, behaviours, rules, tastes, habits, customs, which characterizes the post-Westphalian age.

2 From now on, I will use "sites of authority" and "regulatory regimes" as equivalent terms to describe the current division of power in the global space, resulting from the spreading of the central power of the nation states. 
Thus, legal scholarship has sought to formulate alternative conceptual schemes that could frame the complexity and the fragmentation of the new global $^{3}$ legal order.

The paper chooses to focus on two of the leading theoretical explanations, typically outlined by legal scholars as quite distinct, even antithetical approaches, situated at the opposite poles of the constitutional debate: legal pluralism, a concept that confronts and respects the diversity and the multiplicity of the global legal realm, and global constitutionalism, traditionally related to concepts of unity and hierarchy, whose paradigmatic reference is the state.

The aim of the paper is to establish a theoretical basis, and provide the conceptual tools to square the opposite ideas of pluralism and constitutionalism in a global context, first analysing the guiding lines according to which each model means to order the global legal society (sec. 2, sec. 3), and then hypothesizing how those models may be compatible, even interconnected, converging from opposite poles towards a middle way, a hybrid type of plural constitutionalism, or constitutional pluralism ${ }^{4}$ (sec. 4). Meanwhile, I have to necessarily mention the crucial catalyst role of national highest courts, regional courts,

3 To avoid misunderstandings, some terminological specifications are necessarily required. Global is the most commonly used term to refer to the law of the current world society. It differs from the term international because global encompasses the different types of law of the contemporary time. In this context, the term international law, coined by Jeremy Bentham to indicate the relationships between sovereign states, is to be avoided. Alternative terms are universal law, worldwide law (especially from French scholars, droit mondial) and transnational law. The term transnational does not merely identifies an autonomous legal order emerged across the borders of the national state, a distinct space of global governance with no relation to the model of States; the transnationality is not something we can observe in the empirical facts, but represents a conceptual construction, an artefact to delineate a space apt to the new global legal dynamics; Zumbansen, P.: Carving out Typologies and Accounting for Differences Across Systems: Towards a Methodology of Transnational Constitutionalism. In: M. Rosenfeld, M.-Sajó, A. (eds): The Oxford Handbook of Comparative Constitutional Law. Oxford, 2012. 77 ss. The terms regional or supranational are referred to international organizations, like the European Union, but if we use the term supranational instead of international, it means that we want to stress the cooperative character of the organization whose we are dealing with; Cassese, S.: I tribunali di Babele. I giudici alla ricerca di un nuovo ordine globale. Roma, 2009; Id., Il diritto amministrativo globale: una introduzione. Rivista trimestrale di diritto pubblico, 44 (2005) 2, 331-357. It is worth recalling the distinction by Maria Rosaria Ferrarese between traditional law, intended both as national law and as international law, and the novel law without borders, embodied in the supranational law and the transnational law. While the supranational law has its origin from a political will, from a State, but soon it crosses its borders, the transnational law does the opposite: it has its origin in the global space, as response to the new demands of globalization, to functional differentiation of the legal order, and remains unbound (cf. sec. 3 p. 6 note 27), without a political will and a state anchor. Ferrarese, M. R.: Diritto sconfinato. Roma-Bari, 2006.

${ }^{4}$ This theory can be developed from two different starting points: plural constitutionalism describes those strands of the global constitutionalism literature that take into account the pluralism of the global legal order; the locution constitutional pluralism, instead, underlines the continuum, the progression from the recognition of the contemporary pluralistic world, through the acceptance of the theory of legal pluralism, to its peculiar contribute to the evolution of the model assigning constitutional quality to the pluralistic world. 
international courts, and other bodies with a judicial or quasi-judicial nature, in shaping all those models. ${ }^{5}$

Lastly, I will raise the question, from a constitutional but open point of view, whether it is really worth continuing to adopt a constitutional prospect. Alternative models (the GAL approach, for instance) may provide more suitable solutions for the complexity of the global legal world. However, at the end, a multiple model that attempts to reconcile different approaches, in correspondence to the multiplicity of the current global society, could be the best option.

\section{The model of legal pluralism ${ }^{6}$}

The different strands of the current literature on legal pluralism share the preliminary assumption that clashes among multiple, overlapping legal systems are unavoidable, and sometimes might be even desirable. In fact, legal pluralism is a common condition, recurring in history: a rich legal pluralism characterized Europe in the medieval period, and the common law tradition has always been characterized by a pluralistic nature.

Today, pushed by the centrifugal forces of globalization, ${ }^{7}$ pluralism has re-emerged after having been swept away by the consolidation of state power in the 19th century.

This newest notion of legal pluralism has started to be developed since the end of World War II, first by legal anthropology and legal sociology, and then by comparative law, international law, and socio-legal studies. It is still a major topic in legal literature, and each discipline identifies many different understandings of this term. Such a wide and general

5 The paper embraces the idea of judicial activity as a form of dialogue. Judicial dialogue is a vague and comprehensive concept, and may describe different scenarios: judges, involving also other judicial actors (quasi-judicial bodies, NGOs, private parties, lawyers, groups of experts, panel systems, human rights organizations, etc.) cite each other's decisions, looking beyond their own borders, even when they are not formally compelled to do so, engage in transnational cooperation, but also attend conferences, have face-to-face meetings, and generally become increasingly aware of transnational legal developments. Among all of these dialogical events, the paper chooses to consider just the narrow notion of dialogue as the tendency of national (constitutional and supreme), supranational, and international courts to refer to each other's decisions in their adjudicatory activity.

${ }^{6}$ An inquiry on the definition of legal pluralism could be the object of an autonomous, more exhaustive research, which is beyond the scope of the present paper, but which I would like to undertake soon. I suggest an essential bibliography: Teubner, G.: "Global Bukowina”: Legal Pluralism in the World Society. In: Teubner, G.: Global Law Without A State. Dartmouth, 1997; Merry, S. E.: New Legal Realism and the Ethnography of Transnational Law. Law and Social Inquiry, (2006) 31, 975; Berman, P. S.: The New Legal Pluralism. Annual Review of Law and Social Sciences, 5 (2009), 225; Griffiths, J.: What is Legal Pluralism? Journal of Legal Pluralism, (1986) 24; Delmas-Marty, M.: Les forces imaginantes du droit (II): Le pluralisme ordonné. Seul, Paris, 2006; Bobbio, N.: entry Pluralismo. In: Bobbio, N.-Matteucci, N.-Pasquino, G.: Il dizionario di politica. Torino, 2004.

7 It is worth noting that globalization has unleashed centripetal forces, too. Robertson uses the term glocalization to mean the mutual contamination between centrifugal and centripetal forces, local and global trends. Globalization has produced a double direction movement: global law absorbs specific rules from each single legal orders through a bottom-up approach (universalization), and global law permeates each single legal orders through a top-down approach (de-nationalization). Robertson, R.: Glocalization: Time-Space and Homogeneity-Heterogeneity. In: Featherston, M.-Lash, S.-Robertson, R.: Global Modernities. London, 1995. 
concept requires an immediate clarification about the meaning that I intend to adopt in this work.

In 1986, in his seminal work What is Legal Pluralism?, John Griffiths summarized and consolidated the results of the legal pluralist scholars achieved until then, and provided the basic definition of legal pluralism as "the presence in a social field of more than one legal order". ${ }^{8}$ Radically anti-statist and anti-positivist, Griffiths affirmed that "Legal pluralism is the fact. Legal centralism is a myth, an ideal, a claim, an illusion". ${ }^{9}$ He draws on the idea of ubi societas, ibi ius ${ }^{10}$ by Santi Romano. ${ }^{11}$

For the purposes of this paper, I will share Griffiths' anti-statist position. However, I will not adopt here his sociological and anthropological classic point of view, as it limits the object of inquiry to the relations between "multiple layers of law, usually with different sources of legitimacy, that exist within a single state or society". ${ }^{12}$ Rather, I intend to adhere to those theories that apply a pluralist framework to the global scenario, in order to conceptualize "a world of hybrid legal spaces, where a single act or actor is potentially regulated by multiple legal or quasi-legal regimes". ${ }^{13}$ This kind of legal pluralism doctrine seeks to provide a more realistic alternative to the two traditional theories that interpret the legal world either as a structure of formal state-to-state relations or as an overarching framework of universal norms like in a sort of Hobbesian cosmopolitanism.

The goal of the model of legal pluralism is to observe and describe the global legal space-regulated by a system of global governance- ${ }^{14}$ and realize its condition of profound fragmentation, respecting and preserving it, and at once bringing to light a both internal and external systemic coherence.

Trying to outline the results of the studies on fragmentation, one could say that the pluralist theorists consider fragmentation essentially from two different points of view. On the one hand, fragmentation can be understood as a multi-layered fragmentation, along a vertical axis composed by the States, the supranational or regional bodies, and the international organizations. It is a fragmentation across different levels of governance, from

${ }^{8}$ Griffiths: op. cit. 1.

9 Ibid. 4.

10 Romano, S.: L'ordinamento giuridico. Pisa, 1918.

11 The current concept of legal pluralism is the outcome of the legacy of the past combined with more recent developments connected to the process of globalization. We are witnessing to the reemergence of a social condition which is very similar in its dynamics to the medieval world. It has revived the idea that law cannot be separated from society, as law is already written in the social "tissue" (Harding, S.: Courts in Context. In: Annuario di Diritto Comparato e di Studi Legislativi. Quaderni 1, Napoli, 2012) so that it does not have to do anything else but mirror it (See also Grossi, P.: L'Europa del diritto. Roma-Bari, 2009). And, as a matter of fact, society cannot be totally identified with state, then law has to recognize its plural character.

12 Olgiati, V.: entry Pluralism, Legal. In: Clark, D. S.: Encyclopedia of Law and Society: American and Global Perspectives. Thousand Oaks (CA), 2007.

13 Berman, P. S.: Global Legal Pluralism. Southern California Law Review, 80 (2007), 1155.

14 The concept of governance can be defined as "the process through which the rules systems in place in any social setting are adapted to the needs and purposes of those who live under them". Stone Sweet, A.: Judicialization and the Construction of Governance. Comparative. Political Studies, 32 (1999) 2, 147; or "the social mechanism by which the rules in place in any given community are adapted to the experiences and exigencies of those who live under them". A. Stone Sweet: Judicialization and Construction of Governance. In: Shapiro, M.-Stone-Sweet, A.: On Law, Politics and Judicialization. Oxford, 2002. 55. 
global, through international, supranational, and finally domestic spheres. On the other hand, fragmentation can be intended as a segmentation in a wide range of single regulatory regimes, placed side by side or overlapping on a horizontal plane in the global sphere, each exercising recognizably public governance functions.

In this paper, I prefer to adopt, instead, one single point of view confronting the fragmentation of the global space as a whole: a vision from a panoramic viewpoint, from the top of a hill, that can grasp the plurality of legal orders, put all on the same level, like "islands" in the sea, ${ }^{15}$ connected through bridges, approaching or overlapping like driven by a plate tectonics.

Moreover, what is stressed by the theorists of legal pluralism is not merely multiplicity or diversity, but rather the absence of a set hierarchical model of interaction and the lack of an overarching unity. Also, to remain consistent with the character of absence of hierarchy, in the paper I choose not to deal with my issue distinguishing between the European dimension and the international one. An analysis of legal pluralism and global constitutionalism, first in the European Union, and then in the global context, could be misleading and bring back to a perspective of hierarchical multi-level protection, involving well-known mechanisms of primacy, direct effects and counter-limits. I prefer to envisage the global dimension as a horizontal, moving, dynamic structure, where a multiplicity of actors and different sites of authority exercise those public powers that tend to escape the exclusive state control. States, supranational organizations, international organizations, hybrid public-private and purely private "self-creating or unofficial"16 bodies, share public power in several matters such as trade, investments, environment, fishing, sport, aviation, security, agriculture, food, media, Internet, weapons, financial crisis, terrorism, labour, refugees, pharmaceutical products. Regulatory roles often overlap. In several areas there is more than one regulatory authority, each one with different jurisdiction, and this leads, in turn, to the institution of further bodies to coordinate them.

The world society is subject to a real sectorialization. Accordingly, the regulatory disciplines cannot follow a single model, effective for each sector, but they have to vary according to specific needs, to the functions to be performed sector by sector. Pluralism is an unavoidable and irreversible consequence of the functional differentiation: while at the national level the principle of separation of powers regulates the relations between the organs of the state, at the global level it is at most a criterion of division of functions that operates. ${ }^{17}$ The sectorialization of the system-the specificity of each regime, as well as the differentiation of the rule-makers-is reflected also by the inequality of the guarantees available for the individuals: the disciplines of each sphere present a diversification in the substance of their contents, indeed rights guaranteed in one of these regulatory spheres are not directly the same in other spheres. ${ }^{18}$

15 "In the sea of globality there are only islands of constitutionality" see Teubner, G.: Constitutionalising Polycontextuality. Modern Law Review, 73 (2010).

16 Cassese, S.: Global Administrative law: An Introduction. 2005. 22.

17 Global governance seems to go back to the states' formative experience of "polysynody" (Ibidem), when they used to divide competences between different collegial organs. Here is another instance of the familiar recurring condition of legal pluralism in history.

18 Cassese, S.: La funzione costituzionale dei giudici non statali. Dallo spazio giuridico globale all'ordine giuridico globale. Rivista trimestrale di diritto pubblico, 3 (2007), 609 ss; Dupuy, P. M.: A Doctrinal Debate in the Globalisation Era: On the "Fragmentation" of International Law. European Journal of Legal Studies, (2007) 1, 2 ss. 
Furthermore, multiplication of judicial bodies, together with an increasing body of case law, is overlapping and accumulating (juridification; judicial ubiquity ${ }^{19}$ ). It follows diversity in the substance and also in the enforcement of rights. The process of enforcement of rights establishes many different degrees of protection, for at least three main reasons: firstly, each sectoral regime decides on the establishment of judicial bodies so it happens that regimes with a court co-exist with regimes that do not have it; secondly, when judicial bodies are established, they can present a different degree of maturation and effectiveness; lastly, so there are different regulatory regimes dealing with the same sector as there are different dispute settlement bodies.

Relentlessly, fragmentation multiplies as if we saw it through a kaleidoscope.

Nonetheless, it is not a chaos since each regime is not $a b$-solutus: according to the pluralist scholars, there is a continuous compenetration between the various regulatory regimes (e.g. between the rules of the special regimes and the general international law, between the law of the member states of European Union and the Union law, etc.). On the contrary, some theorists of fragmentation have depicted those sites of authority as selfcontained, self-enclosed, and self-referential regimes, a sort of isolated and self-sufficient monads, with no compenetration, asserting that each system is independent from the general normative framework constituted by the international legal order and act in a "clinical vacuum". ${ }^{20}$

In sum, the theory of legal pluralism "is not just an external description of the constitutional landscape, but is corroborated and reinforced by the deepest role selfunderstanding of the key actors themselves". ${ }^{21}$ Legal pluralism involves the commitment to the common recognition and accommodation of the diverse parts notwithstanding their diversity. This is the crucial factor that distinguishes pluralism from plurality: the plurality remains mere plurality when the different sites of authority are conceived of as separated, fragmented in self-enclosed and self-referential regimes. Instead, the plurality turns into pluralism whether the different expressions of public power are considered connected to each other ${ }^{22}$ and the actors of this plurality are conscious that their own existence depends on their reciprocal relationships.

19 Ferrarese, M. R.: Diritto sconfinato. Inventiva giuridica e spazi nel mondo globale. BariRoma, 2006.

20 See the WTO Appellate Body Report 29 April 1996. 9; Marceau, G.: A Call for Coherence in International Law-Praises for the Prohibition Against "Clinical Isolation". WTO Dispute Settlement Journal of World Trade, 33 (1999) 5, 87-152.

${ }^{21}$ Walker, N.: The Idea of Constitutional Pluralism. EUI Working Paper LAW, (2002) 1.

22 Ferrarese, M. R.: Prima lezione di diritto globale. Roma-Bari, 2012. 10.

Cf also Romano: op. cit. The second part of Romano's book is entitled "The plurality of the legal orders and their relationships": it is interesting to notice that Romano, after having realized the plurality of the legal orders, considers appealing that a jurist deals also with the reciprocal relationships and interactions between such legal orders, their mutual indifference or recognition, and identifies the essence of pluralism in its ordering nature, its interdependence, its dynamic and living condition. 


\section{The model of global constitutionalism}

The international legal order, or the system of global governance, grows up spontaneously, not according to a plan or a political will (political scientists talk about "governance without government”23), indeed, even if it had its origin in the states, it has become increasingly less dependent on them. Consequently, it appears plausible to whom conceives the constitution as consistent to the traditional domestic model, that the global legal order does not rest on any constitutional basis. ${ }^{24}$

In which sense, then, can we talk about a global constitutionalism?

The concept of global constitutionalism is not universally undisputed, and raises skepticism among many scholars. It is not easy to overcome the variety of global constitutionalism literature and the terminological ambiguity to seek and formulate a more straightforward concept of global constitutionalism in order to provide, at least, a common platform to debate it.

Traditionally, the roots of global constitutionalism go back to the post World War II period, when many countries around the world adopted constitutions or bills of rights and established forms of judicial review. The basic function of constitutionalism, deeply dependent on the existence of a written and entrenched constitution put into place by the pouvoir constituant, consists in keeping politics in check and limiting the government, in full compliance with the principles of separation of powers and checks and balances. Therefore, constitutionalism is essential for the survival of democracy, as the opposite is true as well, that democracy is fundamental for the existence itself of constitutionalism. ${ }^{25}$ Then, the quality "global" identifies the tendency of a domestic notion, that one of constitutionalism, to become common to many countries all over the world.

Thus, in its original phase, ${ }^{26}$ global constitutionalism was still tightly tied to the idea of modern nation state, but soon constitutional features would gradually begin to emerge in the international legal order, specifically in the context of supranational arrangements, like

${ }^{23}$ Rosenau, J. N.-Czempiel, E.-O.: Governance without Government: Order and Change in World Politics. Cambridge Studies in International Relations, (1992) 20.

24 Typically, there could be no constitutional discourse without a political community as its object of representation and source of legitimation.

25 Concerning the iterative relationships between constitutionalism and democracy, see, e.g. Walker, N.: Constitutionalism and the Incompleteness of Democracy: An Iterative Relationship. University of Edinburgh School of Law Working Paper, (2010) 25; Ferrarese, M. R.: When National Actors Become Transnational: Transjudicial Dialogue between Democracy and Constitutionalism. vol. 9 Iss. 1 (Frontiers), Article 2, Global Jurist, 2009.

${ }^{26}$ Part of the academic literature agrees on the distinction of the development of the concept of global constitutionalism in three phases, which can be called the "three C's" in global constitutionalism: C1 stands for Constitution; C2 for Constitutionalisation; and C3 refers to Constitutionalism as a novel concept. See Weiner, A.-Lang, A. F.-Jr. Tully, J.-Maduro, M. P.-Kumm, M.: Global Constitutionalism: Human Rights, democracy and the rule of law. 1 Global Constitutionalism, Cambridge, 2012. Another distinction which is relevant to those scholars who consider constitution as a process rather than a thing (see p. 7): big C and small C constitutions. The formal-written, or big C-constitution is not the whole of the constitution but it is complementary with the small $\mathrm{C}$ constitutional culture. The small $\mathrm{C}$ constitution, the constitutional culture, is a product of the patterns of behaviour within a community. Gardbaum, S.: The Place of Constitutional Law in the Legal System. In: Rosenfeld, M.-Sajó, A. (eds): op. cit. 170 ss. 
the European Union (EU), and other international organizations, such as the World Trade Organization (WTO) and the United Nations (UN).

Once this process is started, it is not difficult to gather how much the concept of global constitutionalism has quickly changed in the current constitutional debate.

Originally, global constitutionalism described the worldwide spreading of typically national circumstances, something deeply bound to the state model, but then it appeared less and less tied to national borders, and progressively ceased to identify a clear-cut phenomenon and became an empty box, a theoretical framework through which legal scholarship tried to interpret what was happening on the global field. A proper global constitutional project has now developed as a sort of umbrella notion which covers a broad range of theories seeking to observe and interpret the international dimension through constitutional lenses. These theories have quite different scopes, some just explaining, describing, and mapping, others also shaping and formulating concrete proposals, still others trying to do both; and their field of observation also varies from the global domain as a whole to specific institutional contexts.

According to these theories, constitutionalism has gone through a paradox: de facto it moves beyond national borders and emancipates itself from nation states, but de iure it remains "unbound", ${ }^{27}$ without any formal anchorage or legitimacy. To fill this void, global constitutionalists have developed many different explanations, all starting from the assumption that there are empirical signs and indicators that the international legal order, although pluralistic in structure, is going through a process of "constitutionalization". ${ }^{28}$

Most of global constitutionalist approaches do nothing else but uncritically transfer the state paradigm to the global society. Among those, the one we could refer to as proper global constitutional approach, ${ }^{29}$ emphasizes, as a reaction against and a response to fragmentation, the existence of an overarching constitutional framework encompassing the entire global legal system, and assumes a high level of global consensus on shared ethical values.

This monolithic approach to global constitutionalism varies from some versions that claim an institutional constitutional order-the constitution of the European Union, or the United Nation's world order constitution, ${ }^{30}$-to others that advocate an informal constitutionalisation, a "constitutionalisation of international law", ${ }^{11}$ based on a "higher law

27 Wiener, A.: Constitutionalism Unbound: A Practice Approach to Normativity. Paper prepared for presentation at the round-table "Practice, Ethics and Normativity", Annual Millennium Conference Out Of The Ivory Tower. Weaving the Theories and Practice of International Relations, London School of Economics and Political Science, 22-23 Oct 2011; see also note 3 p. 2.

28 Cass, D. Z.: The "Constitutionalization" of International Trade Law: Judicial NormGeneration as the Engine of Constitutional Development in International Trade. EJIL, 12/1, 2001. 39-75; Bryde, B. O.: Konstitutionalisierung des Völkerrechts und Internationalisierung des Verfassungsrechts. Der Staat, 42 (2003), 62-75.

${ }^{29}$ For the further distinction between global constitutionalist approach and transnational constitutionalist approach, see MacDonald, E.-Shamir-Borer, E.: Meeting the Challenges of Global Governance: Administrative and Constitutional Approaches, Discussion Draft, 2008, available at http://iilj.org/courses/documents/MacDonald.Shamir-Borer.92508.pdf.

30 Fassbender, B.: The United Nations Charter as the Constitution of the International Community. Columbia Journal of International Law, 36 (1998), 529, 573 ss.

31 De Wet, E.: The International Constitutional Order. International and Comparative Law Quarterly, 55, 2006. 51-76. 
constitution",32 or a "multi-tiered system of governance founded on higher law constitutionalism". ${ }^{33}$ Both of those monistic strands, however, have in common closure and a tendency towards a new reduction to unity, that attempt to keep following the old familiar standard of a national constitution within a single hierarchically layered legal and political system.

This sort of constitutional theories are often constructed with reference to comparative constitutional law. ${ }^{34}$ Taking for granted for the moment that judicial bodies are the institutions that most contribute to order the global space, ${ }^{35}$ we could say that the constitutional function of judges is specular to the classic notion of constitution. A national constitution establishes governmental institutions, such as legislatures, executives, and courts, and grants them the power to make, apply, enforce, and interpret laws, and also indicates how the various institutions are expected to interact with one another. We can affirm that judges have a constitutional function, though not depending on any formal constitutional mandate: such a strand of constitutional thinking is based on the idea of a material, substantial, not formal, constitution, considered more as a process rather than as a particular institutional form or structure. Post World War II constitutions usually contain also a catalogue of fundamental rights and liberties that is expected to be enacted by the legislative power, and establish procedures and institutions for protecting rights against political interference, typically in the form of judicial review ("higher law constitution"). Judicial bodies in the new global order have a constitutional function also concerning fundamental rights: they are engaged in a dialogue with foreign courts and interpret foreign constitutions, in doing so they create a common core of values and principles, a common frame of reference ${ }^{36}$ and establish a sort of jurisprudential circle of human rights, replacing an inactive legislator in giving protection to fundamental rights.

One more observation on the argumentation that derives from the historical double meaning of the term "constitution" as something defined that has already settled to represent a political community, but also as a dynamic and ongoing process that is developing over time in a dialectic evolution with the underlying community. ${ }^{37}$ Playing on the constitutive ambiguity of the term constitution itself, the potential elements against the idea of a global constitution can be simply interpreted as a proof of its rudimentary and embryonic nature, its "emerging" 38 character, its function as premise and telos at the same time.

Also, according to this idea, UN, WTO, EU or other regional bodies can be defined as "constitutional" sites of authority. However, this claim is a double-edge sword since it hides some risks that could undermine the basis of this brand of global constitutional thinking: should the constitutional character of some of the entities that coexist in the global world be

32 Stone Sweet, A.: Constitutionalism, Legal Pluralism, and International Regime. Indiana Journal of Global Legal Studies, 16 (2009) 2, 630 ss.

33 Stone Sweet, A.: Judicialization and Construction of Governance. In: Shapiro-Stone Sweet: On Law, Politics and Judicialization. op. cit.

${ }^{34}$ Stone Sweet: Constitutionalism, Legal Pluralism, and International Regime. op. cit. 622.

35 See infra sec. 4, p. 9.

36 See note 40.

37 "A society forms its constitution to bear its identity. But it also forms its constitution to shape its identity”. Allott, P.: Eunomia: New Order for a New World. Oxford, 2001.

38 De Wet, E.: The Emergence of International and Regional Value Systems as a Manifestation of the Emerging International Constitutional Order. Leiden Journal of International Law, 19 (2006), 611. 
viewed as an evidence, or even as a reference model, for a broader global constitutional system, or rather, on the contrary, are they indicative of the absence of any overarching constitutional order at the global level?

A sharper objection concludes that, if the object of global constitutionalism-a fully shaped global constitution-does not exist yet, this should be enough to persuade that a global constitution is just a speculative project, for some others even a totally unrealistic option.

Nonetheless, the major objection to a global constitutional framework is that such a model does not reflect, least of all respect, the pluralistic nature of the reality, rather tends to neutralize and negate it, driven by the ambition of an utopian reduction to unity, claiming to re-impose order and re-establish hierarchy.

\section{Towards the middle way of Plural Constitutionalism}

The global constitutionalism model outlined in the previous section seems to confirm the view that "any measure of legal pluralism is inversely proportional to any measure of constitutional order" ${ }^{39}$

The aim of the paper is to challenge this view and seek to reconcile pluralism and constitutionalism. Pluralism is an inevitable-it represents the conditions we are living-and a more desirable alternative to the pretending unity claimed by the global constitutional discourse, ${ }^{40}$ but also the idea implied in the concept of constitutionalism of "a single authorizing register for the political domain as a whole" 41 is consistent with and necessary to the global society.

In the second part of the paper, I described the global legal world of today as a huge horizontal field where many different players coexist, collide, and build linkages in mutual cooperation through an active dialogue. This plurality of orders on the same plane needs a

39 Stone Sweet: Constitutionalism, Legal Pluralism, and International Regime. op. cit. 631, using this sentence just to contradict it.

40 The invocation of universal norms of human rights is used to to provide political legitimation in absence of a political centre. Human rights argumentation, considering their universal recognition and their evocative and symbolic appeal of universal topoi, is one of the most powerful ways to gain the adherence of the audience for an author. Human rights have the appearance of being able to transcend constitutionalism and act as a source of legitimation. But if at a general level we can agree that general values exist (but we could debated also on this assumption), when we apply those values to a concrete case they become immediately controversial, the problem is not that authoritative interpretative bodies for concretising putatively universal values expressed in HR are lacking, rather is that those values do not mean the same thing. Value diversity is insourmountable, and there is even the risk of a Western imperialism. Pluralism is an ethically preferable alternative to the unrealistic unity implied in global constitutional discourse. Constitutional pluralism is a better option as it satisfies the substantial requirements, and reflects the societal and private interests (Ferrarese: Prima lezione di diritto globale. op. cit.), closer to a sort of global technocracy that escapes from the traditional forms of top-down accountability related to the democratic mechanisms and that finds its legitimation in effectiveness, efficiency, output [Goodwin, M. E. A.: Plugging the legitimacy gap? The ubiquity of human rights and the rhetoric of global constitutionalism. Rechtsfilosofie und Rechtstheorie, 39 (2010) 3]

41 Walker, N.: Constitutionalism and Pluralism in Global Context. RECON Online Working Paper, (2010) 3, 2. 
pragmatic architecture and conceptual tools to be properly understood. To this end, legal pluralism certainly recognizes an external normative coherence of the global order, identifying relatively stable relationships between the different sites of authority. Yet these interactions remain mere coincidences and contingent connections of distinct identities.

A step forward is made by more nuanced, "modest" strands of academic global constitutionalism literature, which could be called transnational constitutionalism approaches, ${ }^{42}$ and in particular by the theory of plural constitutionalism, or constitutional pluralism ${ }^{43}$ mainly developed by Neil Walker. ${ }^{44}$

This theory aims at the reconciliation of plurality in constitutionally meaning terms. To this end, it goes through various stages. Firstly, constitutional pluralist scholars realize the pluralistic essence of the contemporary legal world, making use of the outcomes of the legal pluralism studies as a starting point. Secondly, they recognize to each non-state legal order its own independent constitutional claims, and respect every distinct constitutional site-national, supranational, international-. Thirdly, they provide a normative sense to the global space, recognizing not only single constitutional identities but also the proper constitutional quality of their mutual relationships. The cooperative dimension between constitutional units cannot be represented anymore either by the old Westphalian order of fully sovereign states, or by an equally fully sovereign global state with a global constitution that absorbs and replaces the existing different sites of authority, repositioning the onedimensional sovereign order. Constitutional pluralism provides an alternative interpretation of these connections, playing a crucial role in fostering the conditions under which these connections may occur, and thus progressively stabilizing them.

In this manner, the plurality of constitutional sites is embraced into a "constitutionally reconciled" 45 legal space, although each site develops a constitutional quality in accordance with the particular traditions, social pressures and normative dynamics peculiar to that site itself. Indeed, there is a process of constitutionalisation but there is also the awareness that it is impossible to keep following the "reduction to unity" ambition of the traditional global constitutionalism.

We could try to imagine two opposing poles of a line: one is the fragmentation, which is legal pluralism to excess, the chaos; the other one is the global constitutionalism in its most radical expression that is a hierarchical overarching legal order, where every form of pluralism has been erased. These two extremes gradually loose part of their strong characterization when they start to converge.

The line that links those two points is represented by plural constitutionalism. Therefore, plural constitutionalism, or constitutional pluralism if we start to "walk" from the pluralism extreme, is more a process of constitutionalisation, a double path that starts

42 Supra note 29.

43 Supra note 4.

${ }^{44}$ Walker, N.: The Idea of Constitutional Pluralism. EUI Working Paper LAW, (2002) 1, 26; Weiler, J. H. H. H.: The Constitution of Europe “Do The New Clothes Have an Emperor?" and Other Essays on European Integration. Cambridge, 1999; MacCormick, N.: Questioning Sovereignty? Law, State and nation in the European Commonwealth. Oxford, 1999; Kumm, M.: Who is the Final Arbiter of Constitutionality in Europe? Three Conceptions of the Relationship Between the German Federal Constitutional Court and the European Court of Justice. Common market Law Review, 36 (1999), 351-386.

45 Walker, N.: Reconciling MacCormick: Constitutional Pluralism and the Unity of Practical Reason. Ratio Juris, 24 (2011) 4. 
from two opposite poles and seeks to reach a middle way where pluralism and constitutionalism find a balance.

Therefore, in the current constitutional debate, the issue at stake should concern how we can use the concept of constitutionalism, and not if we can use it or not (all or nothing). ${ }^{46}$ Nowadays, there is no unitary template to decide whether constitutional status is achieved or not, but there are some criteria and standards in terms of which forms of constitutionalism can be distinguished and degrees of constitutionalisation can be identified. Thus, many scholars have reassessed the strong concept of constitutionalism, elaborating substitute models such as of "lite", ${ }^{47}$ or "compensatory"48 constitutionalism, or even viewing constitutionalism more as a "mindset" 49 or a "sensibility". ${ }^{50}$ As I argued in the third section of the paper, constitutionalism starts to become an empty box, when it goes beyond the national borders.

The idea of plural constitutionalism started to be shaped in the context of the studies of the constitutional dimensions of European Union. The European Union has been a kind of original "comfort zone" 51 for the ideas of constitutional pluralism since the Union does appear to possess a constitutional character of sorts (the doctrine of primacy and direct effects; the governance institutional architecture), to have a material constitution-which is thinner, and not thicker as it would be if the formal European Constitution have been approved-, and to establish occasionally interactions with other constitutional identities (the member States).

The idea of plural constitutionalism, in particular, acquires an instant vividness and concreteness from the relationships between national-supreme and constitutional-courts and supranational courts. Courts have a crucial role: they are aware of deciding the specific concrete case, but also of acting in a broader context which their decisions contribute to built. They develop close structural and cultural connections (bridges, passerelle ${ }^{52}$ ) between the different regimes, and, according to those scholars who endorse the process of constitutionalisation, it is plausible that this judicial dialogue may be the key for the construction of properly constitutional relations.

The well-known Kadi judgement ${ }^{53}$ may well prove how judges are exerting a constitutional function, determining the relationships between the different legal layers,

46 Parrish, A. L.: Storm in a Teacup: the U.S. Supreme Court's Use of Foreign Law. University of Illinois Law Review, 13 (2007) 2, 640-642; Poiares Maduro, M.: Three Claims of Constitutional Pluralism. In: Avbelj, M.-Komarek, J.: Constitutional Pluralism in the European Union and Beyond. Oxford Portland, 2012. 1.

47 Klabbers, J.: Constitutionalism Lite. International Organizations L.aw Review, (2004) 1, 32.

48 Peters, A.: Compensatory Constitutionalism: The Function and Potential of Fundamental International Norms and Structure. Leiden Journal of International Law, 19 (2006), 579.

49 Koskenniemi, M.: Constitutionalism as a Mindset: Reflections on Kantian Themes About International Law and Globalization. Theoretical Inquiries in Law, (2007) 8, 9.

50 von Bogdandy, A.-Dann, P.-Goldmann, M.: Developing the Publicness of Public International Law: Towards a Legal Framework for Global Governance Activities. German Law Journal, 9 (2008) 11.

51 Walker: Constitutional and Pluralism in Global Context. op. cit. 11.

52 The term is coined by Cassese: La funzione costituzionale dei giudici non statali. op. cit.

53 Kadi v. Council of European Union; Case C 402/05, delivered on January $18^{\text {th }} 2008$, available at http://eur-lex.europa.eu/LexUriServ/LexUriServ.do?uri=CELEX:62005J0402:EN:HTML. Briefly, the facts. In 2008 the European Court of Justice (ECJ) overruled the decisions of the Court of First 
here in particular between European Union law and international law. Kadi stands for a new "bottom-up" 54 process in which a regional court, the European Court of Justice, tries to persuade the UN Security Council to change its policy towards fundamental rights.

Through this approach, which is very similar to the so-called "Solange stance", 55 judges are building not a hierarchical, pyramidal order, according to a view related to the supremacy of a supranational order, rather they focus on the global dimension, and create a circular network with weak or even absent hierarchies ${ }^{56}$ : a pyramid without its vertex. ${ }^{57}$

Then, the model of plural constitutionalism begins to be conceived also and most of all beyond the European context. We are witnessing the development of new transnational forms of constitutionalism driven by the functional specialism of the increasingly autonomous spheres of the global society ("societal constitutionalism"; 58 "sectoral constitutionalization"59). Nonetheless, can we really state that the process of constitutionalisation of the global order is fully completed?

Instance of the European Communities and annulled the regulations of the Council of European Union implementing the resolutions of the UN Security Council that had placed Mr. Kadi, citizen of Saudi Arabia with important relations with the European Union, and the Al Barakaat International Foundation, based in Sweden, on the list whose funds were to be frozen on suspicion of financing terrorism. The reason of the judgement is that the Court found a breach of fundamental rights guaranteed at the level of the European Union: the right to be heard, the right to property and the principle of proportionality, the right to an effective legal remedy/judicial review. The European Court of Justice (ECJ) reviews the validity of a Community act in the light of fundamental rights. This review "must be considered to be the expression, in a community based on the rule of law, of a constitutional guarantee stemming from the EC Treaty as an autonomous legal system which is not to be prejudiced by an international agreement” (para. 316). The European Court does not establish a new hierarchical structure regarding the interaction between international law and European law. Rather, the Court emphasizes the primacy of obligations under the UN Charter, but at the same time, by emphasizing the rule of law, states that the judicial review also covers all Community acts, even if they are designed merely to give effect to resolutions adopted by the UN Security Council. This is an approach of reciprocal concessions. If there were a real conflict between obligations arising under the UN Charter on the one hand and EU fundamental rights as "principles that form part of the very foundations of the Community legal order" (para. 304) on the other, EU fundamental rights have to prevail. In his opinion, the former Advocate General of ECJ Miguel Maduro: "Measures which are incompatible with the observance of human rights [...] are not acceptable in the Community". Maduro stated, inter alia, that "the relationship between international law and the Community legal order is governed by the Community legal order itself, and international law can permeate that legal order only under the conditions set by the constitutional principles of the Community".

54 Stewart, R. B.: US Administrative Law: A Model for Global Administrative Law? Law and Contemporary Problem, 68 (2005) 63.

55 The reference is obviously to the famous German Solange case. BverfGE 37, 271; 19742 CMLR 540, (1974).

56 Image evoked by Antonio Ruggeri in his speech at the Annual seminar of Gruppo di Pisa "Sovranità statale, costituzionalismo multilivello e dialogo tra le corti”, Scilla, September 21, 2012.

57 Ost, F.-van de Kerchove, M.: De la piramide au réseau? Pour une théorie dialectique du droit. Faculté universitaires de Saint-Louis, 2002.

58 Teubner: op. cit.

59 Peters, A.: Membership in the Global Constitutional Community. In: Klabbers, J.-Peters, A.Ulfstein, G.: The Constitutionalization of International Law. Oxford, 2009. 153-263, 201-203. 


\section{Some concluding remarks. Alternative proposals}

In the previous section, I described plural constitutionalism both as an internal characteristic of the sites of authority and a structural external characteristic of their reciprocal relationships.

It is quite evident that the huge ambition of this model has not been able so far to manage the plurality and at the same time impose a "single authorizing register for the global society as a whole”. 60

Some scholars have proposed a more systematic and encompassing constitutional framework. ${ }^{61}$ Also, this theory is subject to objections: rhetorical excess, inflationary consequences devaluing the symbolic power of the term itself. Even so, Walker replies that "the label constitutional pluralism has been overused and overstretched [...] but what it remains worth thinking about is the architecture of global law in constitutional terms". ${ }^{62}$

However, a better option could be the different approach of global administrative law (GAL). Plural constitutionalism discourse remains overly limited in the institutional forms to which the constitutional character can be usefully applied, ${ }^{63}$ while the global administrative law is a similar approach but provides a necessary complement to it insofar as it encompasses all sites at which public power is exercised, not simply those that can be sensibly referred to as "constitutional”. But also GAL has some shortcomings: it could be exploited as a new tool for the pursuit of hegemonic interests or as a facade of legitimacy to the relations of domination already in existence.

Concluding, we could formulate another hypotesis: a model that attempts to put together more approaches, shifting from a line with two extreme ends to a triangle with moving and dynamic sides, following the model of the classification of the legal systems by Ugo Mattei ${ }^{64}$.

Global governance could be conceived of as a porous space developed, fostered, sustained, mainly through judicial dialogue, by the application of principles and rules of the emerging global administrative law, complemented by a constitutional framework, in which the different actors-thick, thin and non-constitutional sites-will continue to coexist in a relation not of hierarchy but of heterarchy ${ }^{65}$, with the overall configuration not of unity but rather of pluralism, and with advantages of a national system (predictability, certainty, stability) and those of a plural order (flexibility, speed).

60 Supra, note 41.

61 Kumm, M.: The Cosmopolitan Turn in Constitutionalism: On the Relationship between Constitutionalism in and beyond the State. In: Dunoff, J.-Trachtman, J. (eds): Ruling the World? Constitutionalism, International Law and Global Governance. Cambridge, 2009. 258-325; Krisch, N.: Global Administrative Law and the Constitutional Ambition. In: Dobner, P.-Loughlin, M.: The Twilight of Constitutionalism? Oxford, 2010. 245-266.

62 Walker: Constitutionalism and Pluralism in Global Context. op. cit. 7.

63 See Walker: The Idea of Constitutional Pluralism. op. cit. 32 ss. to have an idea of what could be categories and indices of constitutionalism, what are, according to Walker, the features that distinguishes a constitutional sites from a non-constitutional sites.

${ }^{64}$ Mattei, U.: Three Patterns of Law: Taxonomy and Change in the World's Legal System. The American Journal of Comparative Law, (1997) 45.

65 Halberstam, D.: Constitutional Heterarchy: The Centrality of Conflict in the European Union and the United States. In: Dunoff-Trachtman (eds): Ruling the World? Constitutionalism, International Law and Global Governance. op. cit. 326-355. 
That being said, the heated debate concerning the idea of constitutionalism is not simply an intellectual challenge, constituting an end in itself, but is a pressing political challenge, anchored in the social and political world, that claims to give answers and purports to make a difference to that world. "Constitutional reasoning, like all legal reasoning, is a form of practical reasoning" 66 .

66 N. MacCormick, N.: Contemporary Legal Philosophy: The Return of Practical Reason. Journal of Law and Society, 10 (1982), 1-18. 